Please quote as: Ebner, W.; Bretschneider, U.; Leimeister, J. M. \& Krcmar, H. (2008): Virtual communities for innovations: Users' requirements for the development of an academic SAP user group. In: Hawai'i International Conference on System Sciences (HICSS) 2008, Big Island, Hawaii. 


\title{
Virtual Communities for Innovations: Users' requirements for the development of an academic SAP User Group
}

\author{
Winfried Ebner, Ulrich Bretschneider, Marco Leimeister and Helmut Krcmar \\ Technische Universität München, Chair for Information Systems (I17), Boltzmannstraße 3 \\ D - 85748 Garching, Germany, Phone: +49 (89) 289-1 9505 \\ E-Mails: \{ebner; bretschneider; leimeister; krcmar\}@in.tum.de
}

\begin{abstract}
This Research in Progress paper analyses users' requirements for the development of a Virtual Community (VC) for the academic SAP UCC (University Competence Center) User Group. The SAP UCC User Group consists of lecturers and students using SAP Software for educational purposes. Initially, we are targeting the 1,300 existing lecturers in Germany for this community. The objective of the VC is to improve the communication and cooperation between the lecturers and to support the systematic development of innovations in the field of teaching this Enterprise Resource Planning Software. This paper focuses on the diagnosing phase of the applied action research circle. The goal is, firstly to understand the lecturers' point of view und secondly to set the basis for the action planning and realization phase.
\end{abstract}

\section{Introduction and Background}

\subsection{Structure of the paper}

This paper starts with the description of the project background and the theoretical basis of innovations and communities. In the second section, the relevance of the research is discussed and the research question is posed. Section three describes the research approach and methodology used for this research. We analyse the lecturers' situation through field studies and identify information and interaction needs. First findings and corresponding conclusions are presented in section four. This is the foundation for a user-centric socio-technical system design for innovation communities. The objective is to introduce a socially accepted, technically stable and economically reasonable system. By the time of the conference we assume to have implemented this community platform. In section five, this paper concludes with the limitation and further outlook on the research that will be conducted in the future.

\subsection{Project Background}

The University Competence Center (UCC) of the Technische Universität München (TUM) offers an education service providing of SAP systems for institutions of higher education and vocational schools. The UCC meets the special requirements of lecturers using SAP systems in teaching and education [21].

Especially two issues are addressed: Firstly, the core of the support is application service providing (ASP), that includes hardware, installation, maintenance, backup, and technical support. Secondly, the UCC provides "Education Specific Services" such as application support, train the trainer courses, teaching cases, and teaching notes.

The SAP UCC User Group Community of the TUM surpasses 20,000 users, most of which are students. These users represent a large pool of knowledge accumulated from class lectures and practical projects and implementations. This knowledge represents a valuable resource as input for the UCC business activities as well as inspiration for product improvements and new product developments at SAP.

In the past, this community was not nurtured and developed systematically. Therefore, the project "SAP UCC Community for Innovations" was set up. In this paper, the focus is on the development of the sub-community for lecturers throughout Germany. The central goals of this community of practice are better information sharing about UCC activities and the promotion of cooperation between the lecturers by using shared documents and supporting each other in special topics (see (6) in figure 1).

Figure 1 illustrates the different stakeholders and the qualification concept of this academic user group: 


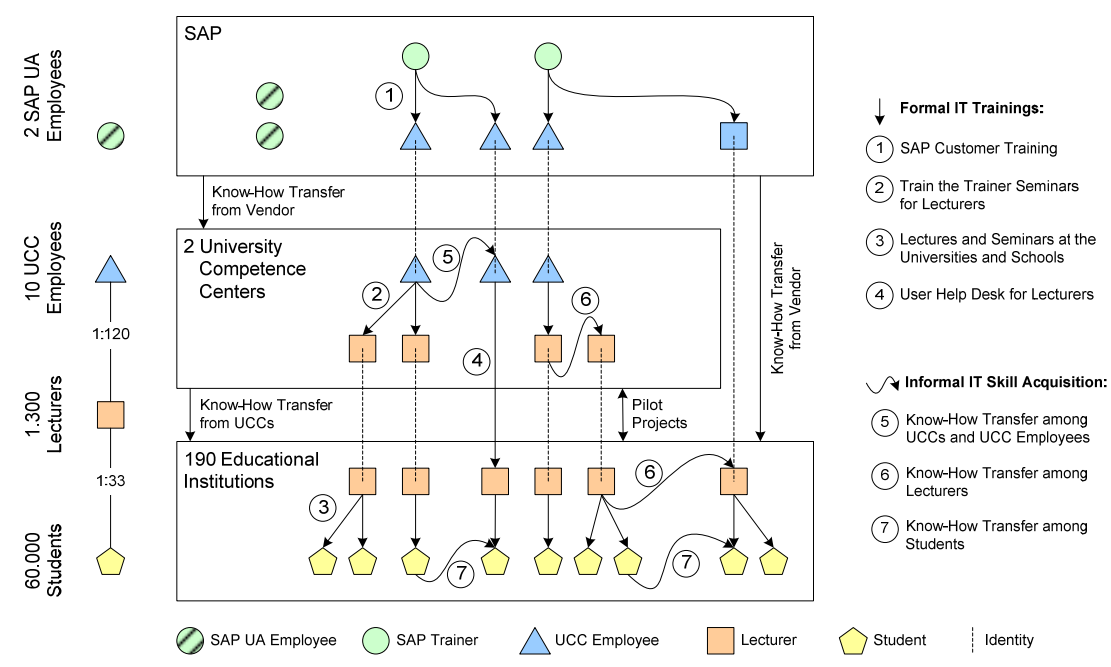

Figure 1: Qualification Concept and stakeholders of SAP UCC Program (Source: Adapted from p 16, [17])

\subsection{Innovations and Communities}

As one of the important success factors for the economic well-being of a company, the implementation of innovations is stated in literature (ср. [22]). The development of new products or services is often connected to high financial investments. Therefore, a series of innovation project failures can harm the company's welfare in a serious way [5].

Traditionally, the research and development departments are the main driver of the company's innovations. Nowadays, the tendency to open up for other resources of innovations becomes more and more important (e.g. employees, suppliers or universities). However, as one of the biggest resource for external innovations the integration of the customers is described by literature. Customer integration is a mode of value creation in which customers are taking part in both operational and innovational value creating activities. These activities used to be seen as the domain of the firm (cp. [30], [20] \& p 2 [33]).

The importance of Community Building as research topic has risen by the development of the World Wide Web and the ongoing virtualization [15]. Starting with the economic perspective of Hagel/Armstrong [9] this area has been reflected scientifically by multiple viewpoints, e.g. business, sociology and psychology (cp. [1], [3], [4], [7], [8], [11], [13], [16] \& [18]). These developments lead to a heterogenic and partly specific body of knowledge within the research community.
However, in-depth research in virtual community building for nurturing innovations has not been accomplished yet.

For connecting the field of Innovations and Community it is helpful to understand the processes of innovation management. As organising principle, the stage model of innovation by Tidd [29] is often used. Figure 2 reflects in which phases of the innovation process communities are most likely to be helpful:

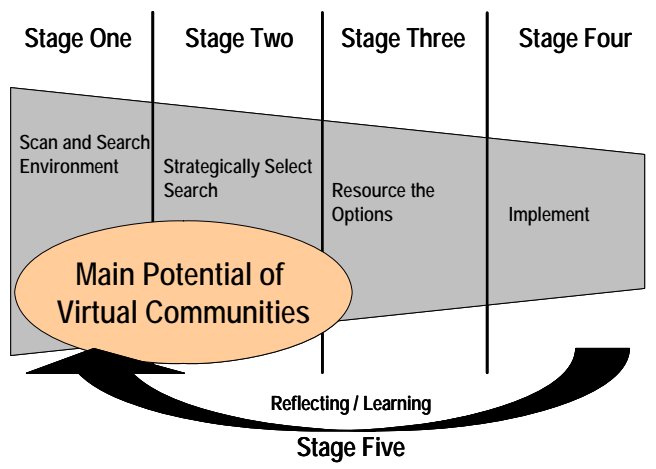

Figure 2: Process of innovation management and potential support of VCs

(Source: Adapted from [29])

Knowing the potential and possibilities of VCs - e.g. in terms of interfaces (cp. [26]) - it is highly probable that the main support of VCs is taking place within the first two stages ("Scan and Search Environment" and "Strategic Select and Search") of the innovation management process. It is also conceivably to use VCs for the reflection and learning phase (Stage Five). 
Sourcing and implementing innovation through VCs is not very likely. Therefore, these stages should be addressed by other organisational options.

Von Hippel states that members of innovation communities "may be generally willing to freely reveal their information”. However, the members are often widely distributed and do have only few innovations to contribute. Making these distributed ideas visible and conveniently accessible to the members of the community will increase their possibility to innovate. Following Hippel and this core functionality, innovation communities are defined as "meaning nodes consisting of individuals or firms interconnected by information transfer links which may involve face-to-face, electronic, or other communication" [32].

\section{Relevance and research questions}

There are two major reasons for the relevance of this topic:

Firstly, there is no systematic scientific approach for communities as a tool to nurture innovations (cp. [33]). But there are incidents that the potential to develop innovations by using the "collective brain" is enormous:

"Large Groups of people are smarter than an elite few, no matter how brilliant - better at solving problems, fostering innovation, coming to wise decisions, even predicting the future."

(Cover of [27])

Jeff Howe condenses this new approach of gaining innovation using the phrase "Crowdsourcing". He describes this new phenomenon as "everyday people using their spare cycles to create content, solve problems, even do corporate R \& D” (p 177, [10]). How to lever this enormous potential of dispersed people is one of the major questions for research and business.

Secondly, SAP and the UCC are highly motivated to use the potential of this community for innovations: "What counts is the speed of transformation - and the business benefits of the new technologies. Innovativeness is the key factor in SAP's success“ [12]. Innovations in this context are twofold: On one hand innovations for the process and products of the relationship between UCC and the educational institutions and on the other hand improvements for SAP products proposed by lecturers and the UCC.

As starting point the following main research question is posed:

Which are the important social and technical requirements for a VC (Virtual Community) with the objective of supporting the generation of innovative ideas?

As literature review shows (cp. [13]), one of the key factors of virtual community building is to raise the requirements of the targeted group. These requirements consist of social and technical dimensions. The economical part is not considered as research topic in this paper.

\section{Research approach and methodology}

This research is designed as an explorative study. As the research object "community for innovations" is new and hardly investigated, general theories about the research object do not yet exist. Stating and validating hypotheses which are purely deduced from theory as common in empirical-analytical research designs cannot be applied here. According to Ulrich, explorative research starts "...in practice, is focused on analysing the context of use and ends in practice" [31].

The intention of this research is to design reality, following the tradition of the Action Research Method, which can be briefly described by its three main characteristics [19, 14]:

- The researcher actively intervenes in a social organization to advance both the organization's well-being and scientific knowledge.

- The project consists of phases of intervention and of reflection for research purposes.

- The researcher has to live up to the ethical challenges of the intervention.

For the design of social innovations like communities, such explorative methods are most fruitful [28, 23]. The procedure of an actions research project is structured in five circular phases. Within figure 3 , these phases are visualized and the research question is dedicated to two phases: 


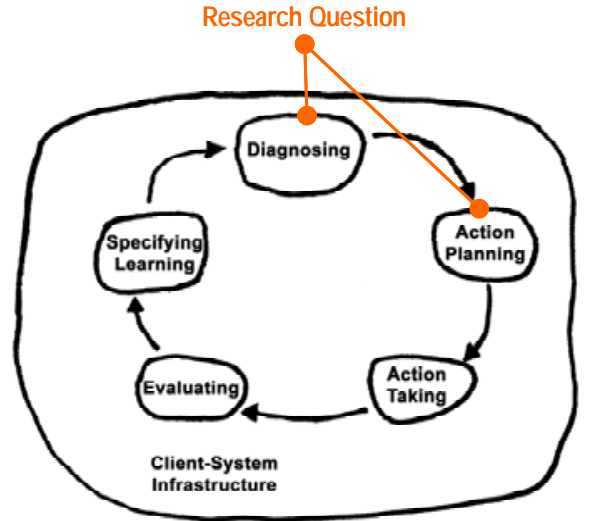

Figure 3: Circle of an action research project and dedication of research question

(Source: Adapted from p 14 [2])

The research question (see section 2) is addressing the diagnosing and action planning phase. These two phases are the foundation for the action taking. The following methods are being used: literature review, analysis of documents, expert interviews and a survey. The following section refers to the survey conducted during the diagnosing phase.
The starting point of the diagnosing phase is a socio-organisational problem (in this case few or no interaction between the existing members of the SAP User Group). An in-depth analysis of the academic lecturers' situation is done through a case study, using interviews, questionnaires, observations and document analysis (cp. [35]. The perspectives on the research objects for analysis are deduced form the Needs-DrivenApproach (NDA) by Schwabe and Krcmar [24]. The NDA was originally developed to design telecooperation [25]. It analyses tasks, work processes, interactions of actors, social structures, tools and shared material, adoption and diffusion of technology, and information storage. These perspectives are the basis for designing survey guidelines and analysing documents.

\section{Findings and Conclusion}

To set up the research question a survey was conducted at the UCC User Group Meeting that has taken place September 14-15th 2006 in Munich. The questions of the survey were deduced from literature review and analysis of existing project documents. Table 1 summarises important design parameters of the study undertaken:

\begin{tabular}{|l|l|}
\hline Method: & Paper-Pencil Survey \\
\hline Foundation: & Literature Review and Documents' analysis \\
\hline Execution: & September, $14-15^{\text {th }} 2006$ \\
\hline Possible Participants: & 332 Registered Users of UCC User Group Meeting \\
\hline Responders / Response & 145 Questionnaires \\
Rate: & $43,7 \%$ Response Rate \\
\hline Organisations of & $30,3 \%$ Lecturers from Universities \\
Participants & $41,4 \%$ Lecturers from Universities of Applied Science \\
& $28,3 \%$ Lecturers of Vocational Schools \\
\hline
\end{tabular}

Table 1: Key Data of the Study

In the introduction of the survey, the project background is explained. This "Community for Innovations" should be developed as a group of people who share a concern or a passion for something they do and learn how to improve as they interact regularly [34].
Firstly, two open questions were posed to find out more about the general expectations of the user group. Figure 4 is illustrating the categorized answers to the question "From $a$ SAP UCC User Group Community I expect ..." 


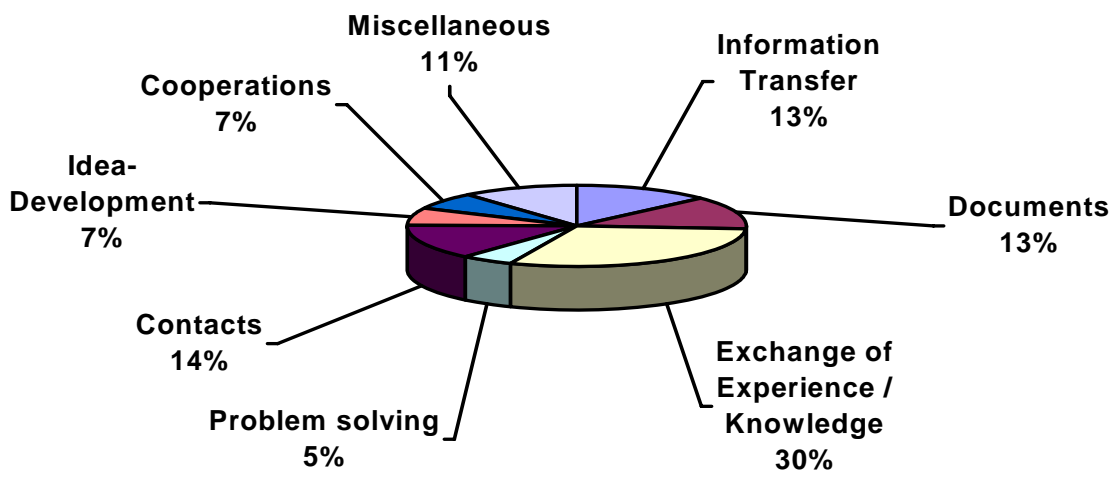

Figure 4: Categorized Answers of positive expectations - 252 Answers in total (Multiple Answers allowed) percentages represent proportion of the category to total answers.

Findings: Nearly every third person (30 \%) answered that this community for innovations should support the exchange of experience / knowledge. $13 \%$ are asking for a better information transfer (from the UCC and UA program) and information accessibility ("Documents"). $14 \%$ of the people want to enhance their contact network.

Conclusions: The IT support to build up the community should focus on communication and collaboration tools to make sure that the users do get the possibility to exchange information. The members of the (offline) community do not know each other very well. The implementation of a "Who-is-Who" and a search for like-minded people is appropriate to meet the requirements.

The second open question was referring to the potential threats. The following categories of responses were identified by asking "Potential threats for a SAP UCC User Group Community could be ..."

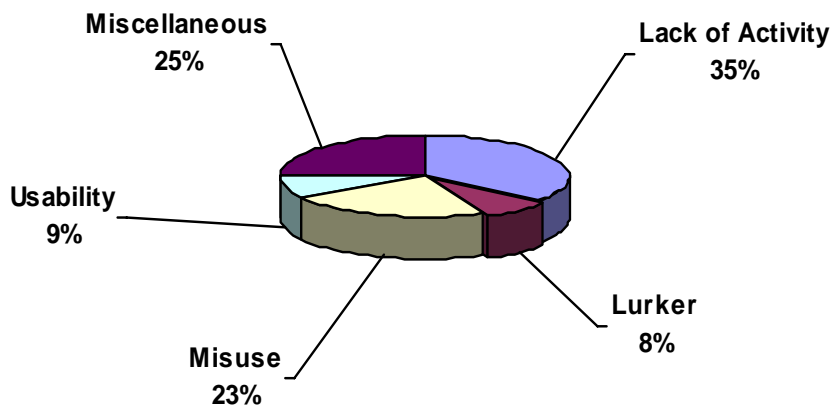

Figure 5: Categorized Answers of potential threats - 104 Answers in total (Multiple Answers allowed) - percentages represent proportion of the category to total answers.

Findings: $35 \%$ of the given answers are stating the "Lack of Activity" as one of the potential threats for the community development. Furthermore, the misuse of the community (e.g. as marketing instrument) by SAP is considered as potential problem. The high percentage of "Miscellaneous" is due to many different but single answers that didn't fit in one category.

Conclusions: Usability of the provided community-tool is only a "hygiene-factor"! The main effort has to be put in the systematic development and nurturing of the community's activity. Rituals can be helpful to counteract the "Lack of Activity” (ср. [13]).

The following two questions ask for the usefulness of proposed community tools for the respondent's daily work - Figure 6 illustrates the community tools of the category "Information / Communication": 


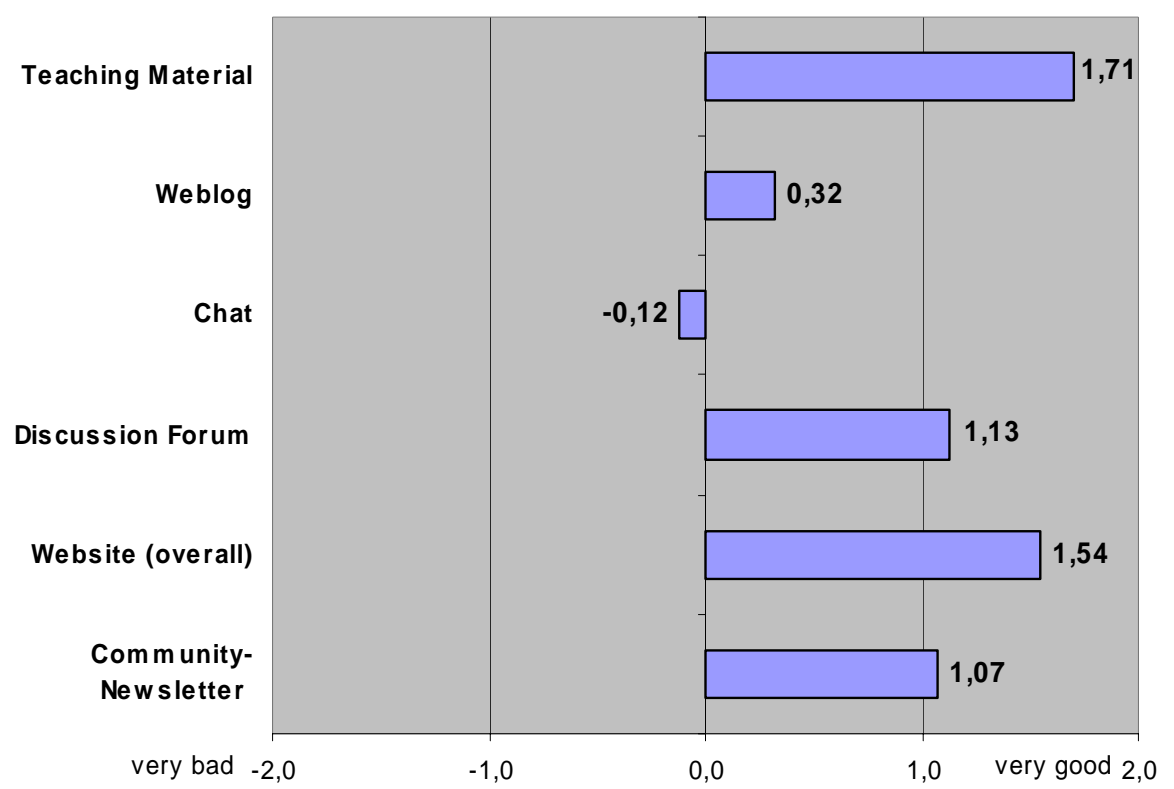

Figure 6: Usefulness of Community Tools for Innovations (Category Information \& Communication) - 145 answers in total - Mean of the Answers on a Scale from -2 (very bad) to 2 (very good). The standard deviation of items is low (in between “ 0.45 ” and “ 0.86 ”).

Findings: Especially providing teaching material was ranked as an almost "very good" tool to support the respondent's daily work (1.71). In addition, tools like discussion forum, newsletter and the website overall (details see figure 7) were identified as useful for the lecturers. By contrast, Weblogs have been middle-rated concerning the usefulness.

Conclusions: The existing website of the community does have the possibility to download some quality assured teaching materials - this possibility of knowledge exchange is not used very intensively, yet. Therefore, a "Best Teaching Material Award" will be announced via the community newsletter. While starting the new platform no weblog or chat will be set up for the users.

To find out more specifically how the community-platform content wise should look like, the question about the usefulness of the following tools on the website has been posed. In figure 7 the results of the category "Website" are shown:

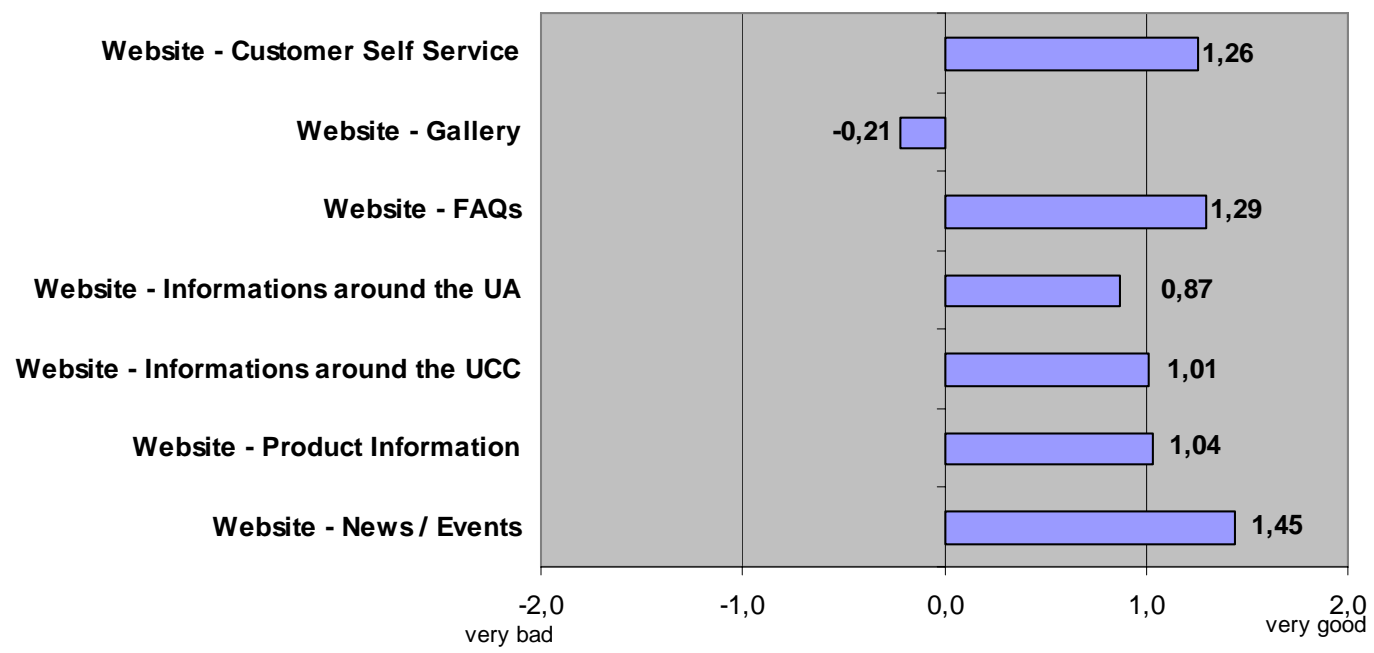

Figure 7: Usefulness of Community Tools for Innovations (Category Website) - 145 answers in total - Mean of the Answers on a Scale from -2 (very bad) to 2 (very good). The standard deviation of items is low (in between " 0.60 " and “0.83”). 
Findings: The community members want to obtain the latest information about news and events which are relevant to the community. The customer self service (a tool, where the users can easily configure administrative issues) and the frequently asked questions are also appropriate tools to support the users daily work.

Conclusions: The information needs, especially in terms of timeliness, are strong and therefore is the demand for information high. The development-process and the content of the existing sporadic newsletter should be overworked. To encourage the self-support within the community a launch of the customer self services is planned.

Summarising the conclusions the research has shown that a socio-technical design for an innovation community has to consider the following issues to be successful:

- Information technology will not be the solution itself. The development of the community has to consider the different motivation patterns of the potential community members, e.g. a distinction between lecturers of universities and vocational schools is essential.

- The information needs, especially in terms of timeliness, can be easily addressed: A higher frequency of the newsletter should help to satisfy these demands.

- To nurture and keep up the activity within the community, events like a "Teaching Material Award" will be announced and specialized groups will be developed (cp. [6]). In addition, a continuous flow of E-Mail will make sure, that the information needs are been satisfied.

\section{Limitations and Future Outlook}

The explorative research approach of the study does have certain limitations. First, due to the self-selection of the user group meeting participants, the research results are not necessarily representative for the entire SAP UCC User Group. Second, not all members of the German user group community have been attending the user group meeting. Third, the survey recorded individual perceptions which might not entirely reflect reality. Fourth, we cannot be sure that all participants share a common understanding of the terms used in the survey, which may have caused biased results.
Further researches should attempt to verify the results by asking selected already active members of the community within expert interviews. The outcome of this mixed method approach will be a detailed action plan for the community building.

\section{References}

[1] Balasubramanian, S. and Mahajan, V. (2001): The economic leverage of the virtual community. International Journal of Electronic Commerce 5 (3), pp 103-138.

[2] Baskerville, R. (1999): Investigating information systems with action research. Communications of the Association of Information Systems 2 (19)

[3] Brunold, J., Merz, H. and Wagner, J. (2000): www.cyber-communities.de - Virtual Communities: Strategie, Umsetzung, Erfolgsfaktoren. Mi, Verlag Moderne Industrie, Landsberg/Lech.

[4] Bullinger, H.-J., Baumann, T., Fröschle, N., Mack, O. and Trunzer, T. (2002): Business communities. Galileo Press, Bonn.

[5] Christensen, C. M. (2003): The innovator's dilemma : The revolutionary book that will change the way you do business. HarperBusiness Essentials, New York, NY.

[6] Cox, A. and Morris, A. (2004): Information Dynamics and Discourse in a Distributed Professional Community. In 37th Annual Hawaii International Conference on System Sciences (HICSS'04), Big Island, Hawaii.

[7] Döring, N. (2003): Sozialpsychologie des Internet : Die Bedeutung des Internet für Kommunikationsprozesse, Identitäten, soziale Beziehungen und Gruppen. Hogrefe, Verl. für Psychologie, Göttingen [u.a.].

[8] Figallo, C. (1998): Tools, techniques \& trust. What makes a good virtual community?: Human and social perspectives. In The First International Conference on Virtual Communities, Bath, UK.

[9] Hagel Iii, J. and Armstrong, A. (1997): Net gain - expanding markets through virtual communities. Thomas Gabler Verlag, Wiesbaden.

[10] Howe, J. (2006): The rise of crowdsourcing. WIRED 06 (6), pp 176-183.

[11] Hummel, J. and Lechner, U. (2002): Social profiles of virtual communities. In 35th Annual Hawaii International Conference on System Sciences (HICSS'02), Big Island, Hawaii. 
[12] Kagermann, H. (2006): Editorial of magazine. SAP-Info : the magazine of the SAP Group, SAP, Walldorf, p 3.

[13] Kim, A. J. (2000): Community building on the web - secret strategies for successful online communities. Peachpit, Berkeley, Calif.

[14] Lau, F. (1997): A review on the use of action research in information systems studies. In Information systems and qualitative research (Degross, J. I. and Lee, A. S. and Liebenau, J., Eds), pp 31-68, Chapman \& Hall.

[15] Leimeister, J. M. (2005): Virtuelle Communities für Patienten: Bedarfsgerechte Entwicklung, Einführung und Betrieb. Dt. Univ.-Verl., Wiesbaden.

[16] Mestad, A., Myrdal, R., Dingsøyr, T., Dybå, T (2007): Building a Learning Organization: Three Phases of Communities of Practice in a Software Consulting Company. In 40th Annual Hawaii International Conference on System Sciences (HICSS'07), Big Island, Hawaii.

[17] Mohr, M., Wittges, H., Nicolescu, V., Krcmar, H. and Schrader, H. (2006): Einbindung und Motivation informeller Multiplikatoren im IT-Training am Beispiel Education Service Providing. In Wirtschaftsinformatik-Ausbildung mit SAP®Software: Reader zum Track der Multikonferenz Wirtschaftsinformatik 2006 in Passau (Krcmar, H. and Rautenstrauch, C. and Wittges, H. and Schrader, H., Eds), pp 1-22, Eul, J, Lohmar.

[18] Preece, J. (2000): Online communities designing usability, supporting sociability. John Wiley and Sons, Chichester, New York, Weinheim, Brisbane, Singapore, Toronto.

[19] Rapoport, R. N. (1970): Three dilemmas in action research. Human Relations 23 (4), pp 499-513.

[20] Reichwald, R., Piller, F. and Ihl, C. (2006): Interaktive Wertschöpfung : Open innovation, Individualisierung und neue formen der Arbeitsteilung. Gabler, Wiesbaden.

[21] Schrader, H. (2005): Früh übt sich. User Group Meeting des University-Alliances-Programms in Magdeburg. SAP INFO 132,

[22] Schumpeter, A. J. (1934): The theory of economic development. Cambridge.

[23] Schwabe, G. (2000): Telekooperation für den Gemeinderat. Kohlhammer Verlag, Stuttgart, Berlin, Köln.

[24] Schwabe, G. and Krcmar, H. (1996): Der Needs Driven Approach: Eine Methode zur Gestaltung von Telekooperation. In Herausforderung Telekooperation
- Einsatzerfahrungen und Lösungsansätze für ökonomische und ökologische, technische und soziale Fragen unserer Gesellschaft (Krcmar, H. and Lewe, H. and Schwabe, G., Eds), pp 69-88, Springer Verlag, Heidelberg.

[25] Schwabe, G. and Krcmar, H. (2000): Digital material in a political work context - the case of CUPARLA. In Proceedings of the 8th European Conference on Information Systems ECIS 2000 (Hansen, H. R. and Bichler, M. and Mahrer, H., Eds).

[26] Shneiderman, B. (2000): Creating creativity: user interfaces for supporting innovation. In: ACM Trans. Comput.-Hum. Interact., Vol. 7, pp 114-138.

[27] Surowiecki, J. (2005): The wisdom of crowds why the many are smarter than the few. First Anchor Books Edition, New York.

[28] Szyperski, N. N (1971): Zur wissensprogrammatischen und forschungsstrategischen Orientierung der Betriebswirtschaft. Zeitschrift für betriebswirtschaftliche Forschung 23, pp 261-282.

[29] Tidd, J., Bessant, J. R. and Pavitt, K. (2005): Managing innovation: Integrating technological, market and organizational change. Wiley, Chichester [u.a.].

[30] Tseng, M. M. and Piller, F. T. (2003): The customer centric enterprise: Advances in mass customization and personalization. Berlin [u. a.] Springer-Verlag.

[31] Ulrich, H. (1981): Die Betriebswirtschaftslehre als anwendungsorientierte Sozialwissenschaft. In: Die Führung des Betriebes. Festschrift für Curt Sandig (Geist, M. N. and Köhler, R., Eds), pp 1-26, Poeschel Verlag, Stuttgart.

[32] von Hippel, E. (2005): Democrizing innovation. MIT Press, pp 93-106.

[33] Walcher, D. (2006): Der Ideenwettbewerb als Methode der aktiven Kundenintegration- eine empirische Untersuchung $\mathrm{zu}$ Eignung und Kundenverhalten mit Implikationen für den Innovationsprozess. Dissertation an der Fakultät für Wirtschaftswissenschaften, München.

[34] Wenger, E. C. and Snyder, W. M. (2000): Communities of practice: The organizational frontier. Harvard Business Review 78 (1), pp 139-145.

[35] Yin, R. K. (1989): Research design issues in using the case study method to study management information systems. In The information systems research challenge: Qualitative research methods (Cash, J. I. and Lawrence, P. R., Eds), pp 1-6, Harvard Press, Boston, Mass. 